\title{
Tooth extraction complication and treatments at the Exodontia Clinic of the Oral and Dental Hospital of the Faculty of Dentistry of Universitas Padjadjaran Bandung
}

\author{
Harnastiti Wirastriajeng, Lucky Riawan, Endang Samsudin \\ Department of Oral and Maxillofacial Surgery Faculty of Dentistry Universitas Padjadjaran \\ Hasan Sadikin Hospital-Bandung, West Java, Indonesia
}

\section{ABSTRACT}

The patient's dental conditions who visited the Exodontia Clinic of the Oral and Dental Hospital of the Faculty of Dentistry of Padjadjaran University, Bandung, were generally in a severe damage stage, causing problems in extraction. This condition, as well as the operator's (co-assistant student) that still have limited capability may increase the risk of complication. This study was conducted at the Exodontia Clinic of the Oral and Dental Hospital of the Faculty of Dentistry of Padjadjaran University. It is conducted from March 13 to May 13, 2007. It is aimed to finding out the types of tooth extraction complications including the treatments to ward the problems. This study was a prospective descriptive using the survey method. The study showed that there was 70 cases $(12.64 \%)$ of complications occured, namely, 37 cases $(6.68 \%)$ in the maxilla, and 33 cases $(5.96 \%)$ in the mandible. The complications that occurred consisted of root fracture $(41.43 \%)$, crown fracture $(32.86 \%)$, soft tissue laceration $(14.29 \%)$, maxillary sinus perforations $(2.86 \%)$, syncope $(2.86 \%)$, swelling $(2.86 \%)$, and secondary hemorrhage (2.86\%). The complications that occurred were well treated.

Key words: Tooth extraction, complication, treatment

\section{INTRODUCTION}

According to Pedlar ${ }^{1}$, dental extraction is a tooth removal procedure performed using forceps and elevator, or transalveolar actions. Meanwhile, according to Dimitroulis ${ }^{2}$, it is a process of removing tooth from the socket.

Each dental extraction has different difficulty level and complication risk. Complication is an unpredicted and adverse event that may result in death if not treated immediately. Tooth extraction complication is a condition outside the normal condition and out of what was expected initially. ${ }^{2}$
The complication can be categorized into two types, intra-operation and post-operation complications. The intra-operation complication includes root and crown fractures, alveolar bone and maxillary tuberosity fractures, bleeding, soft tissue trauma, mandibular fracture, temporomandibular joint dislocation, maxillary sinus perforation, emphysema, nerve trauma, and syncope. The post-operation complication includes dry socket, secondary bleeding, inflammation and trismus, dehycence, hematoma and echymosis. ${ }^{1-3}$

The Oral and Dental Hospital of the Faculty of Dentistry, Universitas Padjadjaran/

Correspondence author: Harnastiti Wirastriajeng, Department of Oral and Maxillofacial Surgery Faculty of Dentistry Universitas Padjadjaran. Jl. Sekeloa Selatan No. 1 Bandung, West Java-Indonesia, Tel./Fax: +6222-2504985/2532805 
RSGM FKG UNPAD Bandung is the first Oral and Dental Hospital in West Java. ${ }^{4}$ RSGM becomes a reference hospital for special oral and dental cases with seven specialist services including oral disease, periodontal disease, dental conservation, prosthodontics, orthodontics, pediatric dentistry, oral and maxillofacial oral surgery. Exodontic clinic is one of the seven service units in RSGM FKG Unpad Bandung. This clinic provides tooth removal service from mild to severe cases. The executors are specialist and resident, but more often the intern student. Because of their limited skills and capabilities, thereisabiggerrisk of dental extraction complication when it is performed by the interns.

The objective and purpose of this study is to find out about tooth extraction complication level in Exodontic Clinic RSGM FKG UNPAD Bandung.

\section{MATERIALS AND METHODS}

This study is a descriptive prospective study using survey method. Observation was performed to patients in Exodontic Clinic Dental and oral hospital Fakulty of Dentistry Universitas Padjadjaran/RSGM FKG UNPAD Bandung who underwent tooth extraction. The complications happened during and after the extraction were examined.

The population is all patients who received tooth extraction at the Exodontic Clinic FKG Unpad RSGM Bandung during the period of 13 March to 13 May 2007. The sampling method used is sampling for time continuous (STFC) based on the stretch of time. Samples are taken from the population who experience upper and lower dental extraction, both men and women.

The study performed by recording each patient identity such as medical record number, name, age, gender, type of teeth, diagnosis and therapist. Then patient is asked to sit on the dental chair. After that, the operator (intern) who worked in Exodontic Clinic performed the extraction and observation was performed to see whether any complication happened during and after the extraction. The patient is given several instructions after extraction and asked to visit the clinic if any complication occured. Follow up visit was performed to monitor the progress on the third and fifth day after extraction.

Data obtained from the observation result is presented in table, graph, and are calculated into percentage.

Table 1. Intra and post-operation complication distribution in lower jaw.

\begin{tabular}{lcccccc}
\hline \multirow{2}{*}{ Type of complication } & \multicolumn{7}{c}{ Type of tooth } & \multirow{2}{*}{ Total } & (\%) \\
\cline { 2 - 5 } & $\mathbf{P}$ & $\mathbf{( \% )}$ & $\mathbf{M}$ & $\mathbf{( \% )}$ & & \\
\hline Root fracture & 0 & 0.00 & 14 & 42.42 & 14 & 42.42 \\
Crown fracture & 1 & 3.03 & 12 & 36.36 & 13 & 39.39 \\
Soft tissue laceration & 2 & 6.06 & 2 & 6.06 & 4 & 12.12 \\
Inflammation & 0 & 0.00 & 1 & 3.03 & 1 & 3.03 \\
Secondary bleeding & & 0.00 & 1 & 3.03 & 1 & 3.3 \\
\hline \multicolumn{1}{c}{ Total } & 3 & 9.09 & 30 & 90.90 & 33 & 100 \\
\hline \multicolumn{1}{c}{} & & & & & & 33
\end{tabular}

Table 2. Intra and post-operation complication distribution in upper jaw.

\begin{tabular}{lcccccc}
\hline \multirow{2}{*}{ Type of complication } & \multicolumn{9}{c}{ Type of tooth } & \multirow{2}{*}{ Total } & (\%) \\
\cline { 2 - 5 } & $\mathbf{P}$ & $\mathbf{( \% )}$ & $\mathbf{M}$ & $\mathbf{( \% )}$ & & \\
\hline Root fracture & 2 & 5.41 & 7 & 18.92 & 16.22 & 40.54 \\
Crown fracture & 0 & 0.00 & 4 & 10.81 & 16.22 & 27.03 \\
Maxillary sinus perforation & 0 & 0.00 & 0 & 0.00 & 5.41 & 5.41 \\
Syncope & 0 & 0.00 & 1 & 2.70 & 2.70 & 5.41 \\
Soft tissue & 0 & 0.00 & 2 & 5.41 & 10.81 & 16.21 \\
Inflammation & 0 & 0.00 & 0 & 0.00 & 2.70 & 2.70 \\
Secondary bleeding & 0 & 0.00 & 1 & 2.70 & 0.00 & 2.70 \\
\hline \multicolumn{1}{c}{ Total } & $\mathbf{2}$ & 5.41 & 15 & 40.54 & 54.05 & 100 \\
\hline
\end{tabular}




\section{RESULTS}

The total number of patients in Exodontic Clinic of RSGM FKG Unpad Bandung in the period of 2 months was 419 individuals consisting of 158 men and 261 women. Of 419 patients, the number of maxillary and mandibular dental extraction was 554 teeth. The most extracted teeth in the upper jaw were molars, i.e. 115 teeth $(20.76 \%)$ and the fewest extracted teeth were canines, i.e. 25 teeth $(4.51 \%)$. The most extracted teeth in lower jaw were molars, i.e. 195 teeth $(35.20 \%)$ and the fewest extracted teeth were canines, i.e. 7 teeth (1.26\%).

Based on the study, there are 70 out of 554 teeth suffered from complications during the extraction. The number of extracted teeth in the upper jaw is 274 teeth with 37 cases $(6.68 \%)$ of complication. There are 280 extracted teeth in lower jaw with 55 cases (5.96\%) of complication. The number of upper jaw complication is bigger than lower jaw complication.

\section{DISCUSSION}

Based on the result, extraction is often performed due to acute caries teeth so the root canal can no longer be treated or only the residual root remains. Generally, patient seeks treatment after the present of pain on the remaining teeth or root.

Caries may occur in all teeth, but usually caries in molar is more frequently found due to its deep fissure so the food residuals are prone to be trapped inside it. The fact that it has more posterior position also makes these teeth difficult to be cleaned. Molar pit and fissure are the locations where caries often occurs and the progression in these locations is faster than in other dental area. ${ }^{5}$

The first molar is the most extracted tooth. This maybe caused by the fact that the first molar is the first erupted tooth so it is easier to be damaged. ${ }^{6}$

There are 70 complication cases of 554 tooth extractions. The most cases happen in upper jaw extraction tooth complication, i.e. 37 cases, while the number of complication cases in lower jaw is 33 cases. This happens because of the teeth have more than two roots or divergent root type.
The apex position of posterior teeth in upper jaw that is very close to sinus cavity also results in complication of sinus perforation. ${ }^{7}$

Molar teeth, especially first molar often experience complication during the extraction, both in upper jaw (13 cases) and lower jaw (20 cases). This tendency maybe due to the number of first molar extraction which is bigger than others so the frequency of complication is also higher.

Tooth extraction complications during this study include root fracture, crown fracture, maxillary sinus perforation, syncope, soft tissue laceration, inflammation, and secondary bleeding. Root fracture is the most frequent complication seen both in upper jaw (15 cases) and lower jaw (14 cases). Generally, root fracture happen due to the vulnerability of the remaining root, wrongextraction technique and operator uncontrolled power.

Based on the result of the study performed in Exodontic Clinic RSGM FKG UNPAD Bandung for 2 month, it can be concluded that the most tooth extraction complication cases seen is root fracture followed by crown fracture, soft tissue laceration, syncope, maxillary sinus perforation, inflammation, and secondary bleeding. All of these complication cases can be well treated.

It is advisable that intern student should notice the correct tooth extraction procedure that include anamnesis, diagnosis, extraction tools selection, extraction technique, and post extraction instruction to avoid complications. X-ray image should be taken before the extraction. The facilities in the Exodontic Clinic of RSGM Bandung such as dental chair and extraction instruments should be well equipped to support the success of process performed by intern student.

\section{REFERENCES}

1. Pedlar J, Frame JW. Oral and maxillofacial surgery. London: Churchill Livingstone; 2001. p. 27,43-6.

2. Dimitroulis GA. Synopsis of minor oral surgery. $1^{\text {st }}$ ed. Oxford: Reed Educational and Profesional Publishing Ltd; 1997. p. 125.

3. Peterson LJ. Contemporary oral and maxillofacial surgery. $3^{\text {rd }}$ ed. St. Louis: Mosby Year Book; 2003. p. 343-46.

4. Surjana H. Gubernur resmikan RSGM Unpad. Republika, 30 Mei 2006. [cited 2007 Jun 24]. 
Available from: http://www.republika.co.id.

5. Kidd, Edwina AM, Joyston-Bechal S. Essentials of dental caries (dasar-dasar karies). Jakarta: EGC; 2003. p. 34.
6. Tarigan R. Karies gigi. Jakarta: Hipokrates; 1990. p. 29.

7. Spiller MS. Extraction. 2000 [cited 2007 Feb 8]. Availablefrom:http://www.doctorspiller.com. 